\title{
Selective stimulation of colonic $L$ cells improves metabolic outcomes in mice
}

\author{
Jo E. Lewis ${ }^{1} \cdot$ Emily L. Miedzybrodzka ${ }^{1} \cdot$ Rachel E. Foreman $^{1} \cdot$ Orla R. M. Woodward $^{1} \cdot$ Richard G. Kay $^{1}$. \\ Deborah A. Goldspink ${ }^{1}$. Fiona M. Gribble ${ }^{1}$ - Frank Reimann ${ }^{1}$
}

Received: 3 December 2019 / Accepted: 3 March 2020 / Published online: 27 April 2020

(C) The Author(s) 2020

\begin{abstract}
Aims/hypothesis Insulin-like peptide-5 (INSL5) is found only in distal colonic L cells, which co-express glucagon-like peptide-1 (GLP-1) and peptide YY (PYY). GLP-1 is a well-known insulin secretagogue, and GLP-1 and PYY are anorexigenic, whereas INSL5 is considered orexigenic. We aimed to clarify the metabolic impact of selective stimulation of distal colonic L cells in mice.

Methods Insl5 promoter-driven expression of Gq-coupled Designer Receptor Exclusively Activated by Designer Drugs (DREADD) was employed to activate distal colonic L cells $\left(\mathrm{L}^{\text {distalDq}}\right)$. IPGTT and food intake were assessed with and without DREADD activation.

Results $\mathrm{L}^{\text {distalDq }}$ cell stimulation with clozapine $N$-oxide (CNO; $0.3 \mathrm{mg} / \mathrm{kg}$ i.p.) increased plasma GLP-1 and PYY (2.67- and 3.31-fold, respectively); INSL5 was not measurable in plasma but was co-secreted with GLP-1 and PYY in vitro. IPGTT (2 g/kg body weight) revealed significantly improved glucose tolerance following CNO injection. CNO-treated mice also exhibited reduced food intake and body weight after $24 \mathrm{~h}$, and increased defecation, the latter being sensitive to 5-hydroxytryptamine (5HT) receptor 3 inhibition. Pre-treatment with a GLP1 receptor-blocking antibody neutralised the CNO-dependent improvement in glucose tolerance but did not affect the reduction in food intake, and an independent group of animals pair-fed to the CNOtreatment group demonstrated attenuated weight loss. Pre-treatment with JNJ-31020028, a neuropeptide Y receptor type 2 antagonist, abolished the CNO-dependent effect on food intake. Assessment of whole body physiology in metabolic cages revealed $\mathrm{L}^{\text {distalDq }}$ cell stimulation increased energy expenditure and increased activity. Acute CNO-induced food intake and glucose homeostasis outcomes were maintained after 2 weeks on a high-fat diet.

Conclusions/interpretation This proof-of-concept study demonstrates that selective distal colonic L cell stimulation has beneficial metabolic outcomes.
\end{abstract}

Keywords Colonic L cells · Enteroendocrine cells · GLP-1 · Glucagon-like peptide-1 · INSL5 · Insulin-like peptide-5 · Peptide YY $\cdot$ PYY

Electronic supplementary material The online version of this article (https://doi.org/10.1007/s00125-020-05149-w) contains peer-reviewed but unedited supplementary material, which is available to authorised users.

Fiona M. Gribble

fmg23@cam.ac.uk

Frank Reimann fr222@cam.ac.uk

1 Wellcome Trust-MRC Institute of Metabolic Science-Metabolic Research Laboratories, University of Cambridge, Cambridge CB2 OQQ, UK

$\begin{array}{ll}\text { Abbreviations } \\ \text { CNO } & \text { Clozapine } N \text {-oxide } \\ \text { DOX } & \text { Doxycycline } \\ \text { DREADD } & \text { Designer Receptors Exclusively } \\ & \text { Activated by Designer Drugs } \\ \text { EEC } & \text { Enteroendocrine cell } \\ \text { GLP } & \text { Glucagon-like peptide } \\ \text { GLP1R } & \text { Glucagon-like peptide-1 receptor } \\ \text { HFD } & \text { High-fat diet } \\ \text { hM3Dq } & \text { DREADD-receptor coupling to } \\ & \text { Gq derived from human muscarinic receptor 3 } \\ \text { 5-HT } & \text { 5-Hydroxytryptamine (serotonin) }\end{array}$




\section{Research in context}

\section{What is already known about this subject?}

- Distal colonic enteroendocrine $L$ cells co-secrete the anorexigenic incretin glucagon-like peptide-1 (GLP-1), anorexigenic peptide YY (PYY) and orexigenic insulin-like peptide-5 (INSL5)

- The importance of colonic $L$ cells for glucose homeostasis and food intake behaviour has been questioned

\section{What is the key question?}

- What, if any, is the physiological outcome of selective stimulation of distal colonic L cells?

\section{What are the new findings?}

- Stimulation of distal colonic L cells improves glucose tolerance in a GLP-1 receptor-dependent manner

- Stimulation of distal colonic $L$ cells reduces food consumption in a manner dependent on neuropeptide $Y$ receptor type 2, whereas GLP1R blockade has little impact on this variable

\section{How might this impact on clinical practice in the foreseeable future?}

- The study confirms colonic $L$ cells as a possible target for pharmacological intervention in diabetes and obesity

$\begin{array}{ll}\text { 5-HT } & \begin{array}{l}\text { 5-Hydroxytryptamine (serotonin) } \\ \text { type 3 (receptor) }\end{array} \\ \text { INSL5 } & \begin{array}{l}\text { Insulin-like peptide-5 } \\ \text { DistalDq }\end{array} \\ \text { Distal colonic L cell expressing hM3Dq } \\ \text { PYY } & \text { Peptide YY } \\ \text { RER } & \text { Respiratory exchange ratio } \\ \text { rtTA } & \text { Reverse tetracycline-controlled transactivator } \\ \text { SCFA } & \text { Short-chain fatty acid } \\ \text { Tet-on } & \text { Tetracycline-activated expression } \\ \text { Y1R } & \text { Neuropeptide Y receptor type 1 } \\ \text { Y2R } & \text { Neuropeptide Y receptor type 2 }\end{array}$

\section{Introduction}

Enteroendocrine cells (EECs) are specialised gastrointestinal epithelial cells that regulate physiological processes ranging from intestinal motility and secretion to glucose homeostasis and appetite [1]. Glucagon-like peptide (GLP)-1, generated from the gene encoding proglucagon $(G c g)$ in intestinal $\mathrm{L}$ cells, has both insulinotropic and anorexigenic activities, underlying the clinical use of GLP-1 mimetics for the treatment of type 2 diabetes and obesity [2]. It is produced alongside another proglucagon product, GLP-2, in increasing amounts in the distal gut, where it is co-stored and released with the anorexigenic hormone peptide YY (PYY). In the distal colon and rectum, L cells also produce insulin-like peptide-5 (INSL5), a hormone with reported orexigenic activity [3], and GLP-1, PYY and INSL5 are co-stored and coreleased from an overlapping vesicular pool in these cells [4]. It remains unclear, however, whether the physiological roles of colonic L cells are restricted to the local control of motility and maintenance of epithelial integrity, or whether they are also metabolically relevant for the control of glucose homeostasis and appetite.

Secretion of most gut hormones is triggered by ingested nutrients, which activate $L$ cells via $G$ protein-coupled receptors and glucose transporters during their absorption across the epithelium. As most nutrient absorption occurs in the proximal small intestine, it is broadly accepted that EECs in the upper gut underlie the elevated plasma levels of GLP-1 and glucose-dependent insulinotropic peptide (GIP) observed early after meal ingestion and the stimulation of insulin secretion via the incretin effect. The physiological roles of $\mathrm{L}$ cells located more distally are less clear. GLP-1 and PYY from L cells in the lower small intestine have been implicated in the ileal brake, responsible for slowing gastric emptying when the rate of nutrient delivery into the duodenum exceeds its capacity for digestion and absorption. Only under exceptional conditions, or long after a meal, do ingested nutrients reach as far as the colon, and it therefore seems unlikely that colonic GLP-1 and PYY contribute to the incretin effect or early postprandial control of appetite [5]. Nevertheless, colonic L cells recapitulate the responsiveness of $\mathrm{L}$ cells from more proximal regions, secreting GLP-1 in response to a range of nutrientrelated stimuli, including glucose in primary cultures [6-8] and perfused colon preparations [9]. L cells in the colon and rectum also express G-protein-coupled receptors for shortchain fatty acids (SCFAs) [10] generated by the intestinal microbiome and for bile acids [11], which are incompletely absorbed in the distal ileum and modified by luminal bacteria, although the physiological importance of SCFAs for the regulation of GLP-1 release remains uncertain [12]. They also express receptors for angiotensin and arginine vasopressin, 
leading to suggestions that the physiological roles of $\mathrm{L}$ cells in the distal gut may involve regulation of local processes such as fluid secretion, motility and intestinal repair [13, 14].

Although the importance of intestinal GLP-1 for the incretin effect has been questioned $[15,16]$, deletion of $G c g$ from the gut epithelium in mice lowered circulating active GLP-1 levels and impaired oral glucose tolerance [17]. When $G c g$ was deleted only from the ileum and colon, active GLP-1 levels were reduced during fasting but not after an oral glucose challenge, suggesting a greater contribution of the distal gut to basal than postprandial GLP-1 release [17]. Not only does the relevance of GLP-1 secretion from distal L cells for glucose homeostasis therefore still remain uncertain, but it is also puzzling that $\mathrm{L}$ cells in the colon and rectum should corelease two anorexigenic hormones (GLP-1, PYY) together with a reportedly orexigenic peptide (INSL5). Understanding the metabolic role of colonic L cells is particularly relevant because the distal gut harbours the majority of endogenous GLP-1 and PYY stores and recruiting this L cell population could be developed as a therapeutic strategy for diabetes and obesity, provided the hormones exhibit metabolic activity when released from this region. That GLP-1 and PYY from the colon would retain metabolic bioactivity is not necessarily a given, first because GLP-1 is rapidly inactivated in the circulation by dipeptidyl peptidase- 4 , and second because any activity of EEC-derived peptides on local nerve endings could have different effects depending on local innervation patterns.

To assess the metabolic importance of distal colonic L cells we developed a new mouse model in which tetracycline (doxycycline, DOX)-inducible Cre-mediated recombination results in expression of Dq-Designer Receptors Exclusively Activated by Designer Drugs (DREADD) only in distal colonic $\left(\mathrm{INSL}^{+}\right) \mathrm{L}$ cells $\left(\mathrm{L}^{\text {distalDq }}\right)$. We assessed whether selective stimulation of these cells by clozapine $\mathrm{N}$-oxide (CNO) can modulate insulin secretion, glucose handling and feeding behaviour and used pharmacological tools to separate the contribution of co-secreted hormones to whole body metabolism.

\section{Methods}

Animals Adult male and female mice (aged 3-6 months) were obtained from colonies maintained at the University of Cambridge under specific-pathogen-free conditions, group housed whenever possible. All animal procedures were approved by the University of Cambridge Animal Welfare and Ethical Review Body and carried out in accordance with the Animals (Scientific Procedures) Act 1986. The work was performed under the UK Home Office project licences 70/ 7824 and PE50F6065. Mice were housed in individual ventilated cages on a $12 \mathrm{~h}$ light/dark cycle (lights out at 07:00 GMT) with unrestricted access to water and regular chow (unless otherwise stated). Mice were allowed to acclimatise to the procedural room $1 \mathrm{~h}$ prior to intervention. Treatment order was randomised (via GraphPad Prism, version 7.9, GraphPad, USA). Animal experimenters were not blinded to treatment; however, hormone assessments were performed by other staff blinded to the treatment. Mice were culled by an approved Schedule 1 method for tissue collection.

\section{Mice strains}

Generation of the tetracycline-dependent expression of reporter genes in Insl5-expressing cells has been previously described [4]. Ins15-rtTA $\times$ GCaMP6f $\triangle \mathrm{CMV}$ mice [4] were used to explore Insl5 promoter driven reporter gene expression in the CNS. To selectively activate Insl5-expressing cells through a designer receptor approach, Ins15-rtTA mice were crossed with Tet-Cre- and CAG-Dq DREADD Cre-reporter mice (stock numbers 006234 and 026220 , respectively, Jackson Laboratory, USA) to create a triple transgenic model (Insl5-rtTA $\times$ Tet-Cre $\times$ Dq). All models were backcrossed for more than eight generations onto a mixed $\mathrm{C} 57 \mathrm{BL} / 6 \mathrm{~J}$ C57BL/6N background and mice of the same background (C57BL/6JN), but negative for Ins15-rtTA, Tet-Cre and CAG-Dq were used as controls.

\section{Transgenic expression and stimulation}

Mice were treated with DOX in the drinking water $(3 \mathrm{mg} / \mathrm{ml}$, with $5 \%$ [wt/vol.] sucrose) for a minimum of 5 days prior to intervention. Mice received either vehicle (PBS with $0.05 \%$ [vol./vol.] DMSO $)$ or CNO $(0.3 \mathrm{mg} / \mathrm{kg}$ in $\mathrm{PBS} / \mathrm{DMSO})$ via i.p. injection. Testing was performed in a randomised crossover design unless otherwise stated.

IPGTT Mice were singly housed and fasted overnight (15 h). At the zero timepoint, glucose was administered at $2 \mathrm{~g} / \mathrm{kg}$ body weight i.p., and vehicle or CNO $(0.3 \mathrm{mg} / \mathrm{kg}$ body weight) was delivered i.p. contralaterally. Blood glucose was measured at $0,15,30,60,90$ and 120 min post administration. Animals were re-fed for $1 \mathrm{~h}$ before re-housing. A minimum duration of 7 days between testing was employed. For the GLP-1 receptor (GLP1R) antagonism studies, animals received either an isotype control antibody or a GLP1R blocking antibody (GLP1R0017), developed in collaboration with MedImmune/AstraZeneca (Cambridge, UK) [18], at $19.2 \mathrm{mg} / \mathrm{kg}$ s.c., $24 \mathrm{~h}$ prior to the IPGTT in a non-crossover design, as described previously [19].

Food intake Mice were singly housed and fasted overnight $(15 \mathrm{~h})$ and body weight was then measured. Vehicle or CNO was administered i.p. as described above. Animals were re-fed and food intake measured at 1,2, 4, 6 and $24 \mathrm{~h}$ post 
administration. Body weight was re-measured at $24 \mathrm{~h}$. A minimum duration of 7 days between testing was employed. For the $\mathrm{Y} 2 \mathrm{R}$ antagonism studies, animals received an i.p. injection of either vehicle or the neuropeptide $\mathrm{Y}$ receptor type 2 (Y2R) antagonist JNJ-31020028 (20 mg/kg), 30 min prior to contralateral administration of vehicle or $\mathrm{CNO}$, and measurement of food intake as described in a non-crossover design. Pairfeeding was achieved by matching the food intake of the treatment group; animals were fed at about 09:00 hours.

Metabolic cages Oxygen consumption $\left(\dot{V} \mathrm{O}_{2}\right)$, carbon dioxide production $\left(\dot{V} \mathrm{CO}_{2}\right)$ and locomotor activity (ambulatory beam breaks) were measured concurrently using a modified open-circuit calorimeter (MetaTrace, Ideas Studio, UK). $\dot{V} \mathrm{O}_{2}$ and $\dot{V} \mathrm{CO}_{2}$ were used to calculate the respiratory exchange ratio (RER) and energy expenditure (EE) as previously described [20]. Mice were placed in the metabolic cages $24 \mathrm{~h}$ before starting the experiment and fasted for $16 \mathrm{~h}$ overnight. Food was reintroduced at time zero, at the start of the recording, when measurements were taken at 12 min intervals.

Defecation Mice were singly housed overnight and transferred to a clean cage prior to testing. One hour after treatment with vehicle or $\mathrm{CNO}$, faecal pellets in the cage were counted and weighed.

Transfer to a high-fat diet Animals previously tested on standard chow were singly housed and transferred to a high-fat diet (HFD; D12451, Open Source Diets, 45\% calories from fat, USA). Animals received either vehicle or $\mathrm{CNO}$ at time zero. Food intake was measured at 1, 2, 4, 5 and 24 h posttransfer to the HFD. Body weight was measured prior to rehousing and initiation of HFD. HFD and body weight were monitored for 2 weeks before repeating the IPGTT and food intake studies.

Plasma glucose and hormones All blood samples were collected into capillary tubes via the tail veil in free-moving, conscious animals. Samples were placed immediately on ice, blood glucose measured ( $5 \mu$ plasma, Accu-Chek, UK) and plasma collected post centrifugation and stored at $-80^{\circ} \mathrm{C}$ until required. Circulating hormones were measured via ELISA (MesoScale Discovery, total GLP-1 and PYY assays, UK) at the Core Biochemical Assay Laboratories, Cambridge, UK. Assay plasma volumes were: insulin $5 \mu$ l, GLP-1 $15 \mu$, PYY $40 \mu \mathrm{l}$.

Immunohistochemistry We prepared $10-\mu$ m-thick colonic and pancreatic sections and $25-\mu \mathrm{m}$-thick brain sections following fixation in $4 \%$ paraformaldehyde (wt/vol.) overnight at $4{ }^{\circ} \mathrm{C}$ and a sucrose gradient $(15 \%$ [wt/vol.] for $6 \mathrm{~h}$, $30 \%$ overnight) as previously described $[4,21]$. Colonic cells positive for INSL5, 5-hydroxytryptamine (5-HT, serotonin), GCG and GFP (for details of antibodies used, see Electronic supplementary material [ESM] Table 1) staining were manually counted and colocalisation assessed using a CellDiscoverer7 (Zeiss, Germany) and imaged using an SP8 confocal microscope (Leica Microsystems, Germany) with a $63 \times$ objective lens. Minor alterations were made during the preparation of coronal CNS section from the previously described method. Mice were anaesthetised with Dolethal (Vetoquinol, Towcester, UK) before being transcardially fixated with 4\% PFA in PBS, as described previously [21]. Tissue postfixed for $24 \mathrm{~h}$ in $4 \%$ PFA overnight and a sucrose gradient (15\% [wt/vol.] for $6 \mathrm{~h}, 30 \%$ overnight) was sectioned using a freezing sliding microtome. Sections were blocked for $1 \mathrm{~h}$ in $5 \%$ donkey serum, $0.3 \%$ (vol./vol.) Tween-20 in PBS, sequentially incubated with GFP antiserum (1:1000, catalogue no. 5450, Abcam), biotinylated donkey anti-goat IgG (1:400, Millipore) and avidin-biotin complex (Vector Laboratories.) and developed using DAB (Abcam), before being dehydrated with an ethanol gradient and mounted with Pertex mounting medium (Pioneer Research Chemicals, PRC/R/750).

Primary cultures Crypts were isolated from the colon/rectum of mice treated with DOX as previously described [4]. Briefly, tissue was digested with $0.35 \mathrm{mg} / \mathrm{ml}$ collagenase type XI (Sigma, USA). Crypts were cultured on 12-well plates precoated with 2\% (vol./vol.) Matrigel (BD Biosciences, USA) in $25 \mathrm{mmol} / 1$ glucose DMEM with $10 \%$ (wt/vol.) FBS, $2 \mathrm{mmol} / 1 \mathrm{~L}$-glutamine, $100 \mathrm{U} / \mathrm{ml}$ penicillin, $0.1 \mathrm{mg} / \mathrm{ml}$ streptomycin and $10 \mu \mathrm{mol} / 1 \mathrm{Y}-27632$ dihydrochloride (Tocris, UK), supplemented with DOX $(0.5 \mu \mathrm{g} / \mathrm{ml})$. Cultures $(24 \mathrm{~h}$ post plating) were washed in warm saline buffer $(138 \mathrm{mmol} /$ $1 \mathrm{NaCl}, 4.5 \mathrm{mmol} / 1 \mathrm{KCl}, 4.2 \mathrm{mmol} / 1 \mathrm{NaHCO}_{3}, 1.2 \mathrm{mmol} / 1$ $\mathrm{NaH}_{2} \mathrm{PO}_{4}, 2.6 \mathrm{mmol} / 1 \mathrm{CaCl}_{2}, 1.2 \mathrm{mmol} / \mathrm{l} \mathrm{MgCl} 2,10 \mathrm{mmol} / \mathrm{l}$ HEPES; pH 7.4; $1 \mathrm{mmol} / 1$ glucose, $0.0005 \%$ [wt/vol.] fatty acid-free BSA) for $30 \mathrm{~min}$ at $37^{\circ} \mathrm{C}$, then incubated for $1 \mathrm{~h}$ at $37^{\circ} \mathrm{C}$ with test agents dissolved in $600 \mu \mathrm{l}$ saline buffer. Cultures were treated with vehicle (control) or $10 \mu \mathrm{mol} / 1$ CNO, or elevated glucose $(10 \mathrm{mM})$ in combinations with forskolin/IBMX (10 $\mu \mathrm{mol} / 1$ each), a positive control for enteroendocrine cell stimulation. Supernatants were centrifuged at $2000 \mathrm{~g}$ for $5 \mathrm{~min}$ at $4{ }^{\circ} \mathrm{C}$ and snap-frozen prior to LC-MS analysis. Cell cultures were lysed $(0.0125 \mathrm{~g} / 1$ deoxycholic acid, $50 \mathrm{mmol} / \mathrm{l}$ Tris- $\mathrm{HCl}, 150 \mathrm{mmol} / \mathrm{l} \mathrm{NaCl}$, $1 \%$ [vol./vol.] IGEPAL CA630, one tablet of EDTA-free protease inhibitor cocktail per $50 \mathrm{ml}$ [Roche Diagnostics, Switzerland]) and protein content measured using a Pierce BCA assay (Thermo Fisher Scientific).

LC-MS Samples were extracted and concentrated as previously described [4]. Mouse sample supernatant fractions were analysed after reduction and alkylation by nanoflow LC-MS using a ThermoScientific Ultimate 3000 nano LC system 
coupled to a Q-Exactive Plus Orbitrap mass spectrometer (ThermoScientific, USA). Relative peptide quantification was performed using Quanbrowser (ThermoScientific) for GLP1(7-37) and GLP-1(7-36)-amide, which were combined to give 'total active GLP-1', INSL5 (A chain), PYY(1-36) and neurotensin by measuring the peptide peak areas in the treated condition compared with the mean of the control-treated cultures. Data were normalised to protein content in primary lysates.

\section{Statistics}

Descriptive statistics (mean \pm SEM) were generated using GraphPad Prism (version 7.0, USA). Data were analysed using Student's $t$ test (unpaired and paired, as appropriate), one- and two-way ANOVA with multiple comparisons (Sidak) and ANCOVA, as appropriate. No animals were excluded from the analyses. A $p$ value of 0.05 was considered significant.

\section{Results}

We showed previously that INSL5 is produced by the majority of L cells in the distal two-thirds of the mouse colon/rectum [22]. Despite previous reports of Ins15expression in the hypothalamus [23], we were unable to detect reporter gene expression in the CNS of DOX-induced Insl5rtTAxGCaMP6 $\triangle$ CMV mice [4], which expressed the reporter in the colon (ESM Fig. 1). To selectively stimulate distal colonic L-cells, we created a new transgenic mouse model in which the reverse tetracycline-controlled transactivator (rtTA) expressed under the control of the Insl5 promoter drives Cre expression under a TET (tetracyclinecontrolled transcriptional activation) promoter. Induction with doxycycline drives Cre-mediated recombination, resulting in the excision of a stop cassette, allowing monocistronic expression of hM3Dq, a DREADD (designer-receptor exclusively activated by designer drugs) based on the human M3 muscarinic receptor and the yellow fluorescent protein Citrine from a

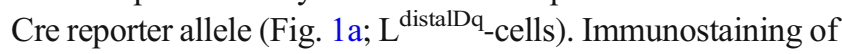
colonic sections from two DOX-treated mice revealed $79 \%$ of INSL5-positive cells stained for GFP, detecting Citrine expression in this mouse model (Fig. 1 bi, c). A small number of GFP-positive cells were also positive for 5-HT $(<5 \%)$, and a small number $(<10 \%)$ of GCG-positive cells also demonstrated immunoreactivity for 5-HT (Fig. 1bii). In addition, sporadic cells in the epithelium stained positive for GFP a
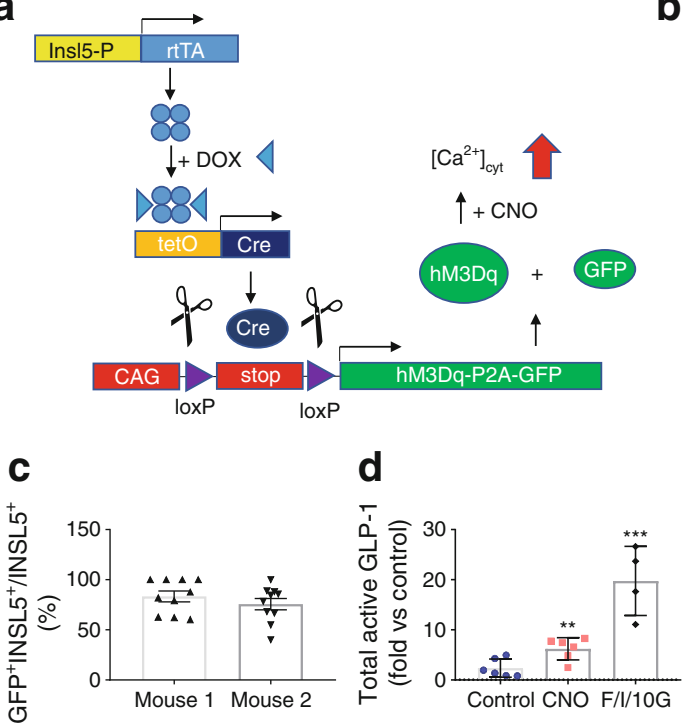

b

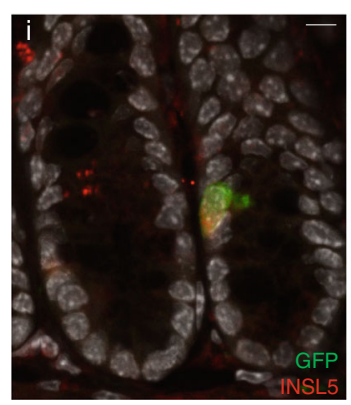

e

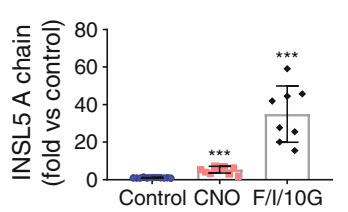

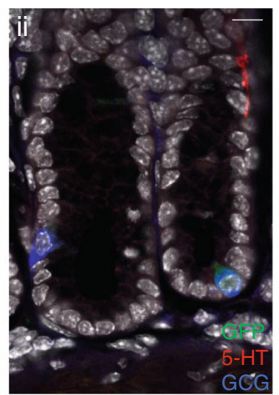

f

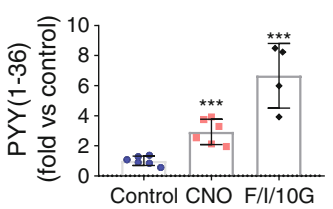

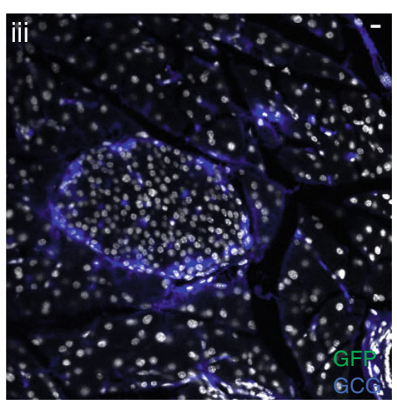

g

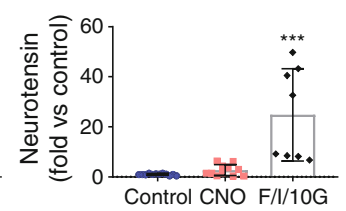

Fig. 1 Characterisation of $\mathrm{L}^{\text {distalDq }}$ model. (a) Tetracycline (DOX)-inducible Cre-mediated recombination system specific to distal L cells resulting in DREADD-hM3Dq expression. The rtTA is expressed under the control of the Insl5 promoter. Induction with DOX ('TET-On') drives a Cremediated recombination, resulting in the excision of a stop cassette, driving expression of hM3Dq-P2A-Citrine (Citrine is a yellow GFP variant) in distal L cells. (b) Representative images from immunohistochemistrybased assessment of Citrine induction in (i, ii) colonic and (iii) pancreatic tissue from DOX-treated Ins15-rtTA $\times$ Tet-Cre $\times$ Dq mice (i) GFP (green)/ INSL5 (red), (ii) GFP (green)/5-HT (red)/GCG (blue) and (iii) GFP (green)/GCG (blue). Scale bars, $10 \mu \mathrm{m}$. (c) Bars represent percentage of INSL5-positive cells that are positive for GFP ( $n=2$ mice). (d-f) GLP-1, INSL5, PYY and neurotensin secreted from mouse colonic cultures $(n=$
$2-4$, in triplicate). Data represent the mean \pm SEM of the fold increase of peptide quantification (peak area) of the treated condition compared with the mean of the vehicle treated control triplicates of the same culture. Conditions: control, $10 \mu \mathrm{mol} / 1 \mathrm{CNO}$ and a combination of forskolin (10 $\mu \mathrm{mol} / \mathrm{l}) 3$-isobutyl-1-methylxanthine (IBMX; $10 \mu \mathrm{mol} / \mathrm{l})$ and glucose $(10 \mathrm{mmol} / \mathrm{l})(\mathrm{F} / \mathrm{I} / 10 \mathrm{G}) . * * p<0.01$ and $* * * p<0.001$ vs control by 1 -way ANOVA with Dunnett's post hoc test performed on $\log _{10}$-transformed data (vs control). CAG, synthetic promoter composed of cytomegalovirus early enhancer element $(\mathrm{C})$, the promoter, the first exon and the first intron of the chicken beta-actin gene (A) and the splice acceptor of the rabbit beta-globin gene (G); Ins15-P, insulin-like peptide 5 gene promoter; P2A, viral 2a 'ribosomal stutter' sequence; stop, stop codon; tetO, tetracycline operator sequence. Circles, vehicle; squares, CNO; diamonds, F/I/10G 
$(<1 \%)$. Hormone secretion from primary mouse colonic cultures from this mouse model was investigated by LC-MS. Cells were stimulated with $10 \mu \mathrm{mol} / 1 \mathrm{CNO}$, a pharmacologically inert metabolite of the atypical antipsychotic drug clozapine and ligand for DREADD-Dq [24], which resulted in a significant increase in GLP-1(7-37), INSL5 (A chain) and PYY(1-36) release (Fig. 1d-f). Neurotensin did not respond to treatment with $\mathrm{CNO}$ (Fig. 1g).

In the fasted state, $15 \mathrm{~min}$ after in vivo stimulation of $\mathrm{L}^{\text {distalDq }}$ cells with CNO (0.3 mg/kg i.p.), GLP-1 and PYY plasma levels were 2.7- and 3.3-fold higher than those observed in mice receiving vehicle stimulation, respectively, and there was a small increase in plasma insulin, $15 \mathrm{~min}$ post administration, (Fig. 2a-c). Effects on GLP-1 (Fig. 2d) and PYY (vehicle 13.2 \pm 2.9 vs CNO 29.2 $\pm 8.4 \mathrm{pmol} / 1, n=4-5$, $p<0.01$ ) were maintained at $30 \mathrm{~min}$. No difference in plasma glucose was observed in the fasting state (Fig. 2e), but in fed mice, stimulation of $\mathrm{L}^{\text {distalDq }}$ cells significantly reduced blood glucose $(p<0.05)$ (Fig. 2f). Given the hormone profile of the animals and the glucose-lowering effect demonstrated by a

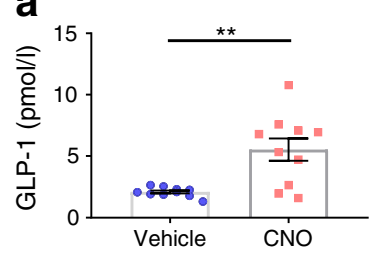

d
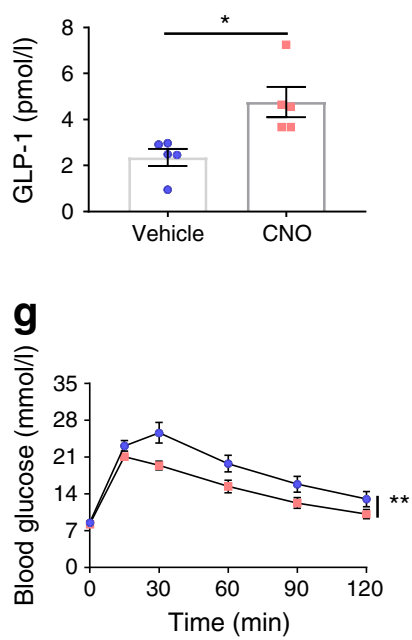

b
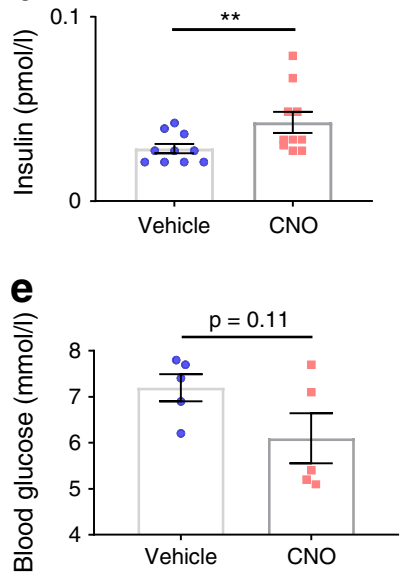

h

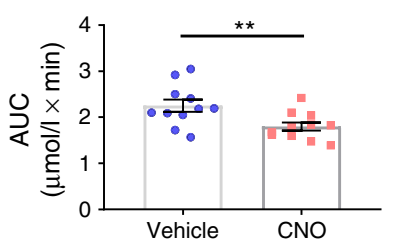

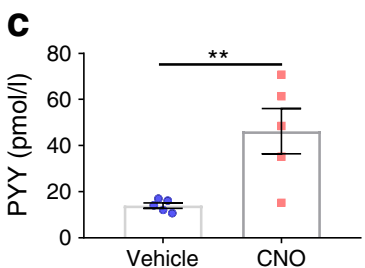

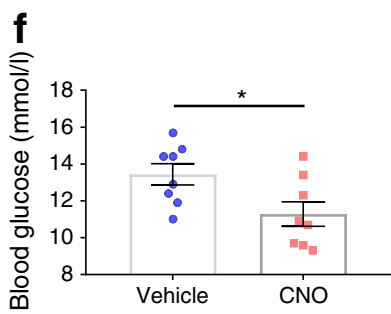

i

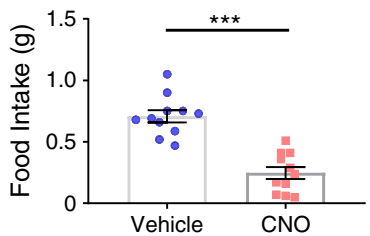

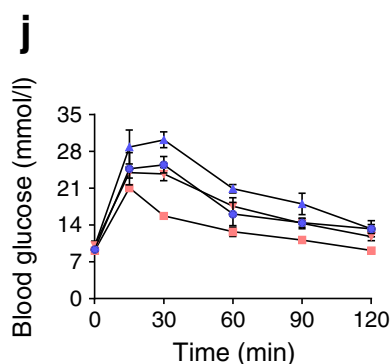

Fig. 2 Colonic L cell stimulation improves glucose tolerance, actions directly attributable to GLP-1. (a) Plasma GLP-1 ( $n=10$, crossover design), (b) insulin [data from same samples as in (a)] and (c) PYY ( $n=5$, non-crossover design) 15 min post administration of vehicle or CNO (at $0.3 \mathrm{mg} / \mathrm{kg}$ i.p.). (d) Plasma GLP-1 ( $n=5$, crossover design) and (e) corresponding blood glucose $30 \mathrm{~min}$ post administration of vehicle or CNO $(0.3 \mathrm{mg} / \mathrm{kg}$ i.p.). (f) Blood glucose in the fed state, $15 \mathrm{~min}$ post administration of CNO. (g) IPGTT ( $2 \mathrm{~g} / \mathrm{kg}$ body weight glucose, administration of vehicle or $\mathrm{CNO}$ (at $0.3 \mathrm{mg} / \mathrm{kg}$ i.p., delivered contralaterally to glucose). (h) AUC and (i) $1 \mathrm{~h}$ food intake post IPGTT ( $2 \mathrm{~h}$ after administration of glucose). Values presented as group mean $\pm \operatorname{SEM}(n=11$, crossover design). Animals were subsequently pre-treated with a GLP1R antibody (GLP1R Ab) or isotype control antibody (Iso-Ab) (j) IPGTT (as previous), (k) AUC and (l) $1 \mathrm{~h}$ food intake post IPGTT post administration of vehicle or CNO $(0.3 \mathrm{mg} / \mathrm{kg}$ i.p., delivered contralaterally to glucose). Values presented as group mean \pm SEM ( $n=5-6$ mice per group). $* p<0.05, * * p<0.01$ and $* * * p<0.001$ by unpaired Student's $t$ test (c), paired Student's $t$ test $(\mathbf{a}, \mathbf{b}, \mathbf{d}, \mathbf{e}, \mathbf{f}, \mathbf{h}, \mathbf{i}), 1-$ way ANOVA with Dunnett's post hoc test $(\mathbf{k}, \mathbf{l})$ or 2-way ANOVA $(\mathbf{g}, \mathbf{j})$. Circles, vehicle; squares, CNO treated; triangles (up), GLP1R ab + vehicle; triangles (down), GLP1R + CNO 
$\mathrm{L}^{\text {distalDq }}$ cell stimulation in the fed state, we further explored the effects of $\mathrm{L}^{\text {distalDq }}$ cell stimulation on glucose tolerance. An IPGTT ( $2 \mathrm{~g} / \mathrm{kg}$ body weight), revealed significantly improved glucose tolerance following $\mathrm{L}^{\text {distalDq }}$ cell stimulation $(p<0.01)$ (Fig. $2 \mathrm{~g}, \mathrm{~h})$. Interestingly, upon refeeding postIPGTT, food intake was significantly lower following CNO treatment, $(p<0.0001)$ (Fig. 2i). Blockade of GLP1R with a monoclonal antagonistic antibody (GLP1R0017) impaired the CNO-triggered reduction in plasma glucose following an IPGTT (Fig. 2j,k). However, the effect on food intake was maintained (Fig. 21).

To further explore this effect, we monitored food intake for $24 \mathrm{~h}$ post administration of $\mathrm{CNO}$, which we had previously shown to have no effect on food intake in $\mathrm{C} 57 \mathrm{BL} / 6 \mathrm{JN}$ control mice [21]. Following an overnight fast, food intake was significantly reduced following $\mathrm{L}^{\text {distalDq }}$ cell stimulation $(p<0.001)$
(Fig. 3a). Presumably as a result of the reduced food intake, body weight was significantly reduced $(p<0.001)$ (Fig. 3b). An independent group of animals pair-fed to the treatment group demonstrated attenuated body weight change compared with the CNO group $(p<0.05)$ (Fig. 3b). This suggested an effect on energy expenditure, which was therefore assessed using metabolic cages. To mimic the home-cage data, following an $8 \mathrm{~h}$ habitation period, animals were fasted overnight and then re-fed prior to treatment with $\mathrm{CNO}$. Whereas the vehicle-treated group exhibited an increase in RER when food was reintroduced owing to the switch to carbohydrate oxidation, $\mathrm{L}^{\text {distalDq }}$ cell activation prevented this increase, and this is likely to be because mice continued to oxidise lipid as food intake was suppressed $(p<0.001)$ (Fig. 3c). Energy expenditure and activity levels were higher in the $\mathrm{CNO}$-treated group (Fig. 3d,e and ESM Fig. 2a,b). Higher energy expenditure a
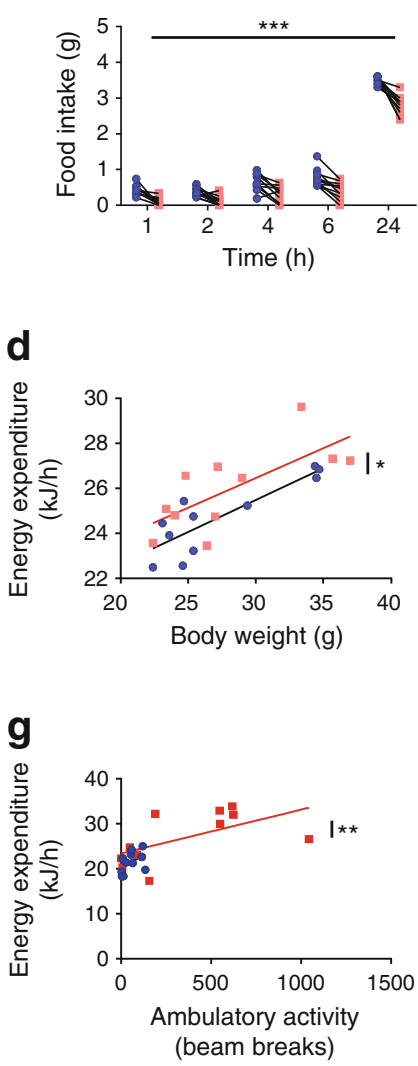

b

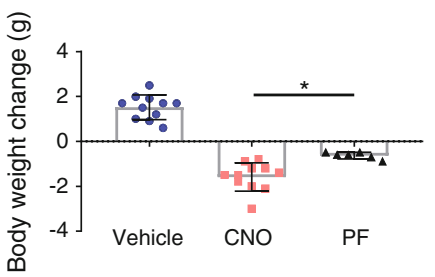

e

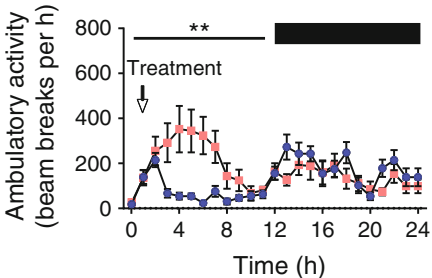

h

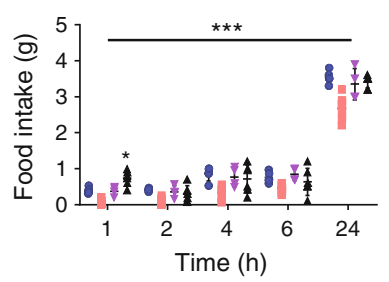

C

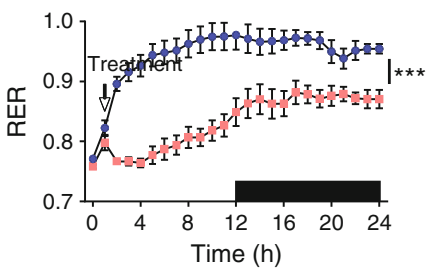

f

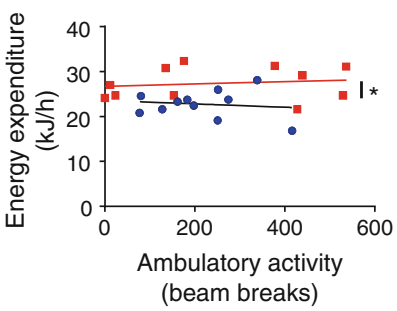

i

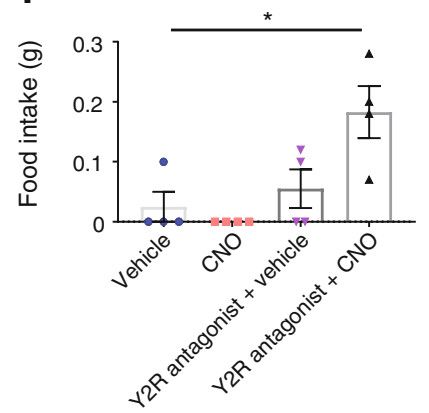

Fig. 3 Colonic L cell stimulation reduces food intake, actions directly attributable to PYY, and increases energy expenditure, a consequence of increased activity. (a) Food intake post administration of vehicle or $\mathrm{CNO}$ ( $n=11$, crossover design). (b) Body weight change over the $24 \mathrm{~h}$ period, including a pair-fed group (PF) which demonstrate attenuated weight loss. (c) RER, (d) Energy expenditure, (e) ambulatory activity and energy expenditure $1 \mathrm{~h}(\mathbf{f})$ and $2 \mathrm{~h}(\mathrm{~g})$ post treatment vs ambulatory activity for mice treated with vehicle or CNO ( $n=11$, crossover design). (h, i) Food intake of animals pre-treated $(t=-30 \mathrm{~min})$ with JNJ-31020028
(20 mg/kg i.p.) post administration of vehicle or CNO $(0.3 \mathrm{mg} / \mathrm{kg}$ i.p., delivered contralaterally to vehicle or antagonist pre-treatment, $n=4-8$ mice per group). Animals in (h) had been transiently fasted as in ( $\mathbf{a}-\mathbf{g})$ whereas animals in (i) had free access to food. Values presented as group mean \pm SEM. $* p<0.05$, ** $p<0.01$, *** $p<0.001$ by 1 -way ANOVA with Dunnett's post hoc test $(\mathbf{b}, \mathbf{i}), 2$-way ANOVA $(\mathbf{a}, \mathbf{c}, \mathbf{e}, \mathbf{h})$ or ANCOVA $(\mathbf{d}, \mathbf{f}, \mathbf{g})$. Blue symbols, vehicle; Red symbols, CNO, triangles (down), Y2R antagonist + vehicle; triangles (up), Y2R antagonist + CNO. Dark phase is indicated by black bars in $\mathbf{c}$ and $\mathbf{e}$ 
was evident in the first hour after $\mathrm{CNO}$ injection when activity levels were similar (Fig. 3f); by $2 \mathrm{~h}$, the two groups were different both in terms of activity and energy expenditure (Fig. 3g). RER, energy expenditure and activity were unaffected by CNO in C57BL/6JN control mice (ESM Fig. 2c-e).

The effect of CNO on food intake was abolished by pretreatment with JNJ-31020028 (Fig. 3h), a selective brainpenetrant small molecule antagonist of the neuropeptide $\mathrm{Y} 2$ receptor, Y2R $[25,26]$. Interestingly, mice that were pretreated with the $\mathrm{Y} 2 \mathrm{R}$ antagonist and then administered CNO ate significantly more than the control group that received vehicle alone $1 \mathrm{~h}$ post stimulation of $\mathrm{L}^{\text {distalDq }}$ cells (Fig. 3h, $p<0.05$ ), suggesting that stimulating $\mathrm{L}^{\text {distalDq }}$ cells might release an orexigenic factor unmasked after blocking Y2R. We repeated this experiment in the fed state, and found that stimulation of $\mathrm{L}^{\text {distalDq }}$ cells in combination with Y2R antagonism resulted in increased food intake $1 \mathrm{~h}$ post administration of CNO (Fig. 3i, $p<0.05$ ).

In addition, we observed that mice exhibited increased faecal output in response to $\mathrm{L}^{\text {distalDq }}$ cell stimulation, measured either by pellet number or weight (Fig. 4a,b). The effect was abolished by the 5-HT type $3\left(5-\mathrm{HT}_{3}\right)$ receptor antagonist ondansetron (Fig. 4c,d) but unaffected by blockage of Y2R (by JNJ-31020028) (Fig. 4e,f), Y1R (BIBO3304) [27] or GLP1R (antagonistic antibody, GLP1R0017) (Fig. 4g-j).

Initial exposure to an HFD generally results in hyperphagia. Stimulating $\mathrm{L}^{\text {distalDq }}$ cells at the time of transfer to an HFD reduced food intake and body weight change $(p<0.01$ and $p<0.001$, respectively) (Fig. 5a,b). Exposure to an HFD ( 2 weeks) significantly increased body weight $(p<0.01)$ (Fig. 5c). Activation of $\mathrm{L}^{\text {distalDq }}$ cells after 2 weeks on an HFD significantly improved glucose tolerance (blood glucose levels and AUC, as assessed by IPGTT) compared with vehicle ( $p<0.001$ and $p<0.0001$, respectively) (Fig. $5 \mathrm{~d}, \mathrm{e})$. Under HFD conditions, activation of $\mathrm{L}^{\text {distalDq }}$ cells also reduced food intake and body weight ( $p<0.01$ and $p<0.001$, respectively) (Fig. 5f,g), mirroring observations in chow-fed mice.

\section{Discussion}

Utilising a novel INSL5-Dq-DREADD mouse model, this study verifies the colon as an endocrine organ, as products from distal $\mathrm{L}$ cells were detected in the circulation and affected glucose tolerance, food intake and body weight. CNOtriggered stimulation of INSL $5^{+} \mathrm{L}$ cells in primary colonic cultures triggered secretion of GLP-1, INSL5 and PYY, and in vivo increased plasma GLP-1 and PYY, improved glucose tolerance and reduced food intake.

The concept of GLP-1 as a gut-derived incretin hormone is not new but is currently controversial, as recent publications have identified the pancreas as a potential alternative source of GLP-1 $[15,16,28]$. Original reports had identified the

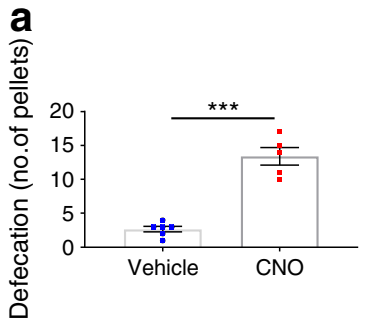

b
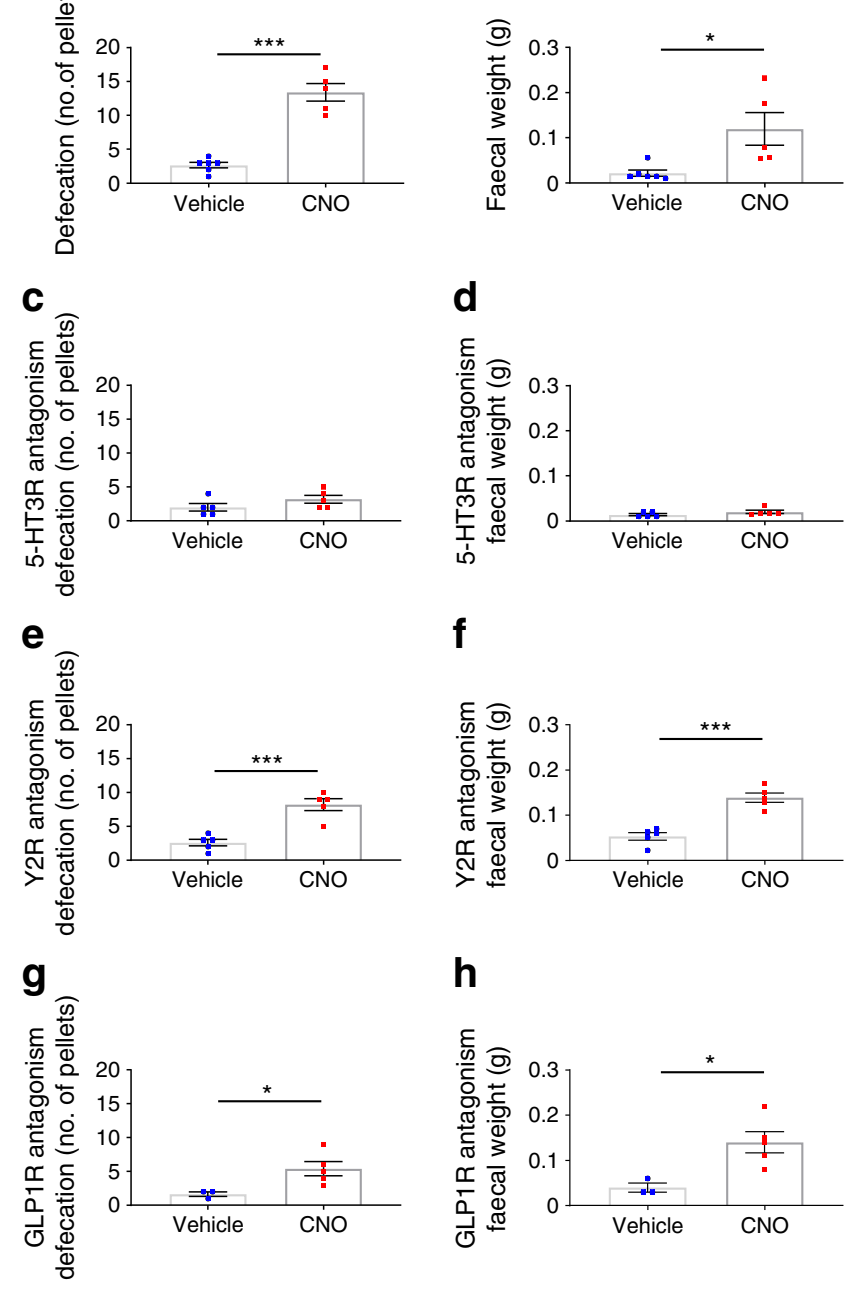

h
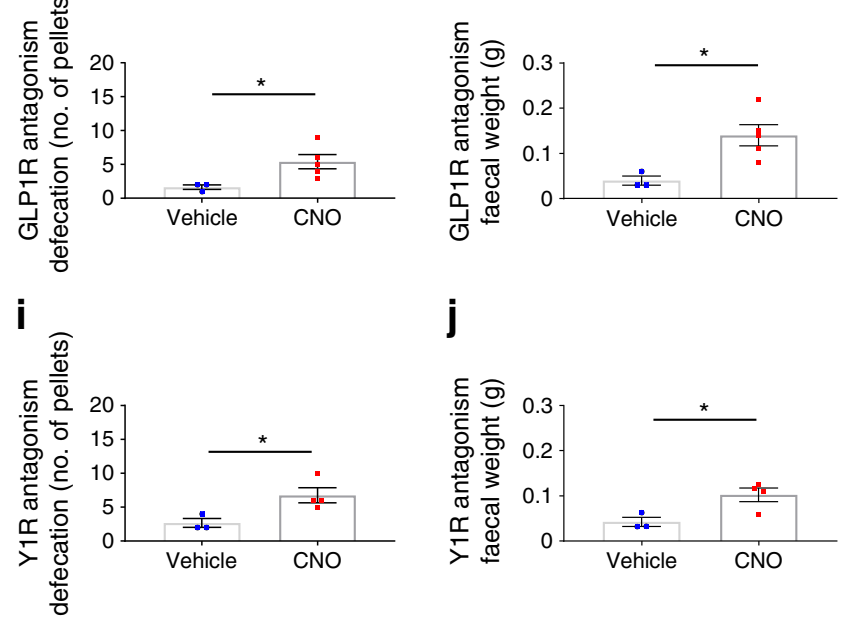

j

Fig. 4 Colonic L cell stimulation increases faecal output, an effect dependent on $5-\mathrm{HT}_{3}$ receptor (5-HT3R) signalling. Defecation quantified as faecal pellet output $(\mathbf{a}, \mathbf{c}, \mathbf{e}, \mathbf{g}, \mathbf{i})$ and faecal weight $(\mathbf{b}, \mathbf{d}, \mathbf{f}, \mathbf{h}, \mathbf{j})$ in response to vehicle or $\mathrm{CNO}(0.3 \mathrm{mg} / \mathrm{kg}$ i.p. $)$ in $\mathrm{L}^{\text {distalDq }}$ animals $(\mathbf{a}, \mathbf{b})$ without or after pre-treatment with (c, d) ondansetron ( $3 \mathrm{mg} / \mathrm{kg}$ i.p.), (e, f) Y2R antagonist JNJ-31020028 (20 mg/kg i.p.), (g, h) Y1R antagonist BIBO3304 (100 $\mu 10.4$ mmol/1 i.p.) or (i, j) GLP1R Ab (GLP1R0017; $19.2 \mathrm{mg} / \mathrm{kg}$ s.c.). Values are group mean $\pm \operatorname{SEM}(n=3-5$ mice per group, non-crossover design). $* p<0.05, * * * p<0.001$ by an unpaired Student's $t$ test. Circles, vehicle; squares, $\mathrm{CNO}$

intestine as the site of bioactive GLP-1 production, whereas pancreatic extracts and perfusates contained very little [29, 30]. Pancreatic alpha cells were also shown to normally process proglucagon to generate $\mathrm{N}$-terminally extended 
Fig. 5 The effects on glucose tolerance and food intake are maintained following exposure to HFD. (a) Food intake and (b) body weight change (in g) following initial exposure to an HFD ( $n=5-6$ mice per group). (c) Body weight gain (in \%) following 2 weeks of exposure to an HFD. (d) IPGTT (2 g/kg glucose), (e) AUC post administration of vehicle or $\mathrm{CNO}$ $(0.3 \mathrm{mg} / \mathrm{kg}$ i.p., delivered contralaterally to glucose, $n=5$, crossover design). (f) Food intake and (g) body weight change post administration of vehicle or $\mathrm{CNO}$ $(0.3 \mathrm{mg} / \mathrm{kg}$ i.p., $n=5$, crossover design). Values are group mean \pm SEM. $* * p<0.01, * * * p<0.001$ by unpaired Student's $t$ test (b), paired Student's $t$ test $(\mathbf{c}, \mathbf{e}, \mathbf{g})$ or 2-way ANOVA (a, d, f). Circles, vehicle; squares, $\mathrm{CNO}$
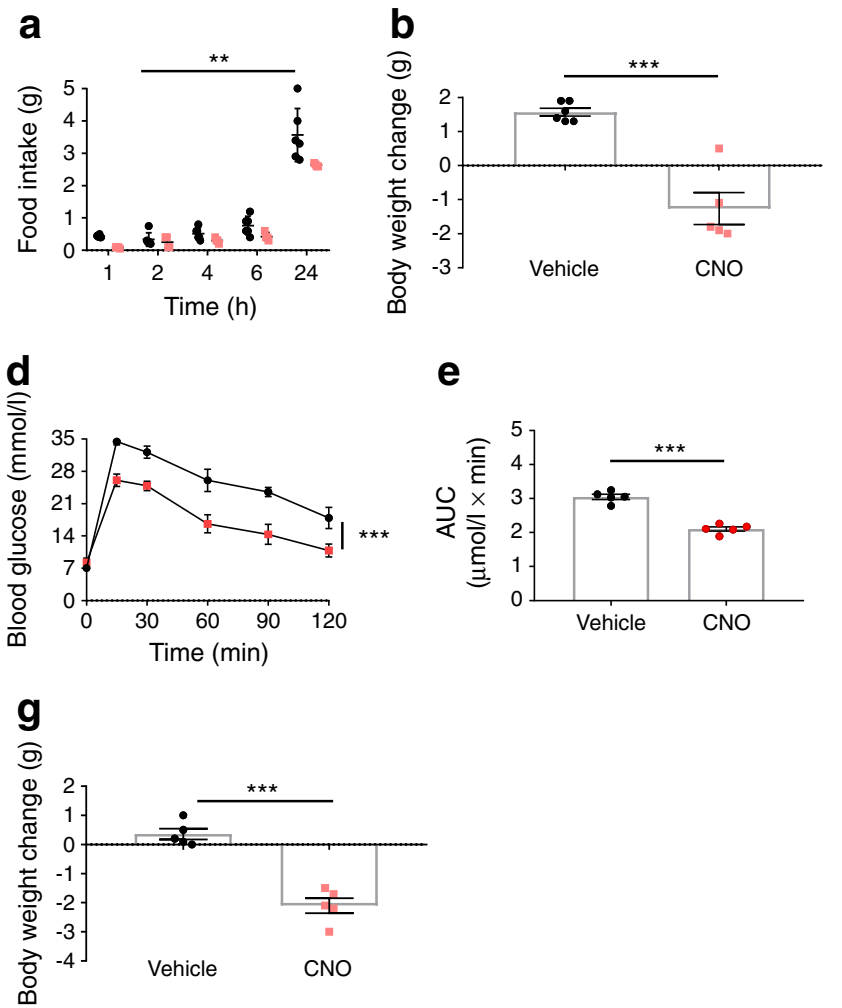

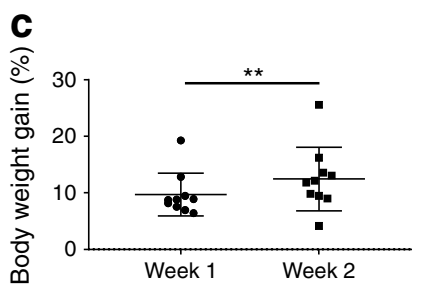

f

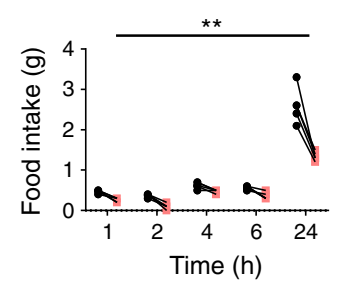

inactive GLP-1 peptides [31]. Plasma GLP-1 levels increase following oral glucose or meal ingestion, but not after intravenous glucose administration, suggesting the circulating peptide is largely gut-derived [32], whereas islet GLP-1 production has largely been reported in models of inflammation and diabetes [17, 33]. However, reactivation of $G c g$ expression in the pancreas (using a pancreatic and duodenal homeobox-1 $[P d x 1]$ promoter), but not the intestine (using a villin [Vil1] promoter) in a Gcg knockout background had an effect on insulin secretion sensitive to the GLP1R blocker exendin-9-39 [15], leading the authors to conclude an important role for pancreatic GLP-1. Although paracrine GLP-1mediated signalling from pancreatic alpha to beta cells was proposed, it was subsequently shown that glucagon, present at much higher concentrations than active GLP-1 in the pancreas, is likely to dominate any intra-islet GLP1R-dependent stimulation of pancreatic beta cells [30, 34-36]. By default, a mechanism entirely dependent on intra-islet crosstalk cannot underlie the incretin effect, as islets require a signal additional to a plasma glucose rise to recognise if the glucose arises from intestinal absorption; for intra-islet crosstalk to participate in the incretin effect, this additional information would have to be supplied by another means, such as autonomic nervous signals initiated by the intestine. Despite previous reports of INSL5-positive hypothalamic neurons [23], we were unable to demonstrate GFP-immunostaining in the CNS of Ins15rtTA $\times$ GCaMP6f mice. Whilst this might be due to limited DOX penetration of the CNS [37], together with the absence of detectable GFP signals in the pancreas of Ins15-rtTAxTetCrexDq mice (Fig. 1biii), this strongly supports a peripheral, intestinal origin of the observed effects on glucose homeostasis and feeding in response to CNO. Our data thus demonstrate that direct colonic L cell stimulation improves glucose tolerance via GLP-1, as the effect was blocked by a GLP1R antagonistic antibody. Given the scarcity of vagal innervation of the distal colon, an afferent signal triggering a vagal reflex to the pancreas and release of pancreatic GLP1R-agonist seems unlikely, and a classical endocrine signalling pathway from the gut to the pancreas seems the most probable explanation for our findings.

The inhibition of food intake triggered by $\mathrm{L}^{\text {distalDq }}$ cell stimulation was not prevented by GLP1R antagonism, but instead seemed attributable to PYY, as it was abolished by the Y2R inhibitor JNJ-31020028. Surprisingly, Y2R antagonism unmasked an orexigenic effect of stimulating colonic $\mathrm{L}$ cells in the fasted and fed state, which we speculate may be attributable to INSL5. Unfortunately, we are unable to measure plasma INSL5 in mice, but we demonstrated that INSL5 was co-released with PYY and GLP-1 by CNOmediated stimulation of $\mathrm{L}^{\text {distalDq }}$ cells in vitro, consistent with our previous report that all three peptides are co-packaged into the same vesicular pool in these cells [4]. In the absence of Y2R antagonism, however, the anorexigenic effect of PYY dominated the effect of $\mathrm{L}^{\text {distalDq }}$ cell activation on food intake, suggesting that any low-level orexigenic activity of $\mathrm{L}$ cellreleased peptides is physiologically unimportant. Further 
investigation into the role of colonic INSL5 is, nevertheless, warranted given the mixed reports that it exhibits orexigenic activity [3], modulates hepatic glucose production [38] and/or stimulates insulin secretion [39]. Although we also here observe a possible orexigenic effect of INSL5, others have failed to observe effects on food intake even at pharmacological doses of chemically synthesised INSL5 (native and pegylated forms) [40].

Interestingly, the reduced body weight observed following $\mathrm{L}^{\text {distalDq }}$ cell stimulation seems to be a consequence not only of reduced food intake, but also of increased energy expenditure, as demonstrated by our pair-fed group and studies in metabolic cages. The difference in RER between the $\mathrm{CNO}$ and vehicle groups appears profound but is likely to reflect food intake, with control mice switching to carbohydrate oxidation as they re-feed on chow following the overnight fast, whereas the $\mathrm{CNO}$ group continued to burn fat as food intake was suppressed. The explanation for the higher activity and energy expenditure of CNO-treated mice remains unclear and seems unlikely to be attributable to GLP-1 or PYY, which have been characterised extensively in the literature. Whilst we did not formally test whether GLP1R or Y2R blockade prevented these effects using metabolic cages, visual observations of mice treated with GLP1R antibody or JNJ-31020028 prior to $\mathrm{CNO}$ injection suggested that increased locomotor activity was still observed in the presence of these inhibitors. Oxyntomodulin, which is co-produced with GLP-1 from the proglucagon peptide in $\mathrm{L}$ cells, has been shown to increase energy expenditure, likely through its activity on the glucagon receptor, although it was not found to increase locomotor activity [41, 42].

$\mathrm{L}^{\text {distalDq }}$ cell stimulation increased faecal weight and pellet number; effects that were abolished by pre-treatment with ondansetron, an inhibitor of $5-\mathrm{HT}_{3}$ receptors. Both $5-\mathrm{HT}_{3}$ and $5-\mathrm{HT}_{4}$ receptors have been implicated previously in regulating faecal output in mice [43, 44]. Studies in mice lacking $T p h 1$, the enzyme responsible for mucosal 5-HT production, also concluded that enterochromaffin cells are important for propagation of colonic migrating motor complexes and pellet propulsion [45]. Our results suggest that enterochromaffin cells were activated by $\mathrm{L}^{\text {distalDq }}$ cell stimulation. Direct activation of enterochromaffin cells seems unlikely, as only a small number of GFP-labelled cells stained positive for 5-HT, consistent with previous reports of only a small overlap of Gcg and Tph1-expressing cells in the small intestine [46] and colon [22]. Although we cannot exclude that direct CNO stimulation of rare cells positive for both INSL5 and 5-HT might have been sufficient to activate faecal expulsion, we speculate that $\mathrm{L}^{\text {distalDq }}$ cell stimulation indirectly activated enterochromaffin cells via paracrine crosstalk. Enterochromaffin cells have been shown previously to express Glp $1 r$ [47], but antagonism of GLP1R did not prevent the increased faecal output in our model. Other possible enterochromaffin targets for $\mathrm{L}$ cell products include Y1R and relaxin/insulin-like family peptide receptor 4 (RXFP4), the receptor for INSL5, mRNA for which we found to be expressed in colonic Tph1-positive cells [22]. Both Y1R and RXFP4 are predominantly $\mathrm{G}_{\mathrm{i}}$-coupled, but pertussis toxinsensitive stimulation of 5-HT release has been shown downstream of $\alpha_{2}$-adrenergic stimulation [48]. However, Y1R inhibition had no effect on accelerated faecal output in our model, consistent with NPY and/or PYY knockout resulting in increased rather than decreased faecal output in response to restraint-stress [27, 49], despite an apparent inhibition of colonic transit by Y1R inhibition in vitro [27].

Conclusions and outlook The physiological roles of colonic $\mathrm{L}$ cells, which contain a large proportion of the body's endogenous reserves of GLP-1 and PYY, still remain a mystery, but our results indicate they would be good targets for small molecules aiming to increase GLP-1 and PYY release for the treatment of diabetes and obesity. Supporting this idea, ingestion of propionate ester, which stimulates release of GLP-1 and PYY from colonic L cells via the SCFA receptor known as free fatty acid receptor 2 (FFAR2), reduced energy intake and weight gain in humans [50], and rectal administration of bile acids in human volunteers also decreased blood glucose and food intake, and it is likely that this occurs via G-proteincoupled bile acid receptor 1 (GPBAR1) [51]. Colonic L cells are enriched for a variety of G-protein-coupled receptors, but although it would be tempting to speculate that these might be targetable with non-absorbable gut-restricted small molecules, several of the receptors seem to be located basolaterally on $\mathrm{L}$ cells $[12,52,53]$, requiring local drug absorption. It will be particularly interesting to discover whether maximal pharmacological stimulation of colonic L cells in humans is capable of reproducing the very high postprandial GLP-1 and PYY levels observed after bariatric surgery, and whether stimulating colonic L cells can mimic the beneficial effects of surgery on glucose metabolism and body weight.

Acknowledgements We would like to thank G. Strachan (IMS Imaging Core), the IMS Disease Model Core (DMC), the Core Biochemical Assay Laboratory (CBAL) and the MRC Metabolic Diseases Unit (MC_UU_ 00014/5) for technical support. The GLP1R-blocking antibody GLP1R0017 was developed by E. Biggs during her PhD in collaboration with MedImmune and we thank AstraZeneca for its provision for this project; for inquiries regarding the use of GLP1R0017 please contact FR, FMG and P. Ravn (email: Peter.Ravn@astrazeneca.com).

Data availability Data are available on request from the authors.

Funding This research was funded by a Wellcome joint investigator award to FR/FMG (106262/Z/14/Z and 106263/Z/14/Z) and a joint MRC programme within the Metabolic Diseases Unit (MRC_MC_UU_ 12012/3). The LC-MS instrument was funded by the MRC 'Innovative Technologies for Stratified and Experimental Medicine' grant (MR/ M009041/1). REF is a BBSRC-iCase PhD student in collaboration with LGC; ORMW is a BBSRC-iCase PhD student in collaboration with 
AstraZeneca and ELM is a Wellcome Trust (Metabolic and Cardiovascular Disease programme) $\mathrm{PhD}$ student. None of the funders were involved in the design of the study; the collection, analysis and interpretation of data; writing the report; and did not impose any restrictions regarding the publication of the report.

Authors' relationships and activities The FR/FMG lab receives additional grant support from AstraZeneca, Eli Lilly and LGC for unrelated work. FMG is a consultant for Kallyope (New York, USA). DAG has started employment with GlaxoSmithKline since contributing to this work. All authors declare that there are no relationships or activities that might bias, or be perceived to bias, their work.

Contribution statement The mouse model was generated by FR and characterised by JEL and ORMW. In vivo studies were carried out by JEL. Expression analysis was conducted by JEL and DAG. Primary cultures were conducted by ELM. ELM, REF and RGK performed the mass spectrometry. JEL, FMG and FR designed the studies and all authors contributed to data acquisition, analysis and/or interpretation, contributed to the drafting of the manuscript and approved the final manuscript. FMG and FR are the guarantors of this work.

Open Access This article is licensed under a Creative Commons Attribution 4.0 International License, which permits use, sharing, adaptation, distribution and reproduction in any medium or format, as long as you give appropriate credit to the original author(s) and the source, provide a link to the Creative Commons licence, and indicate if changes were made. The images or other third party material in this article are included in the article's Creative Commons licence, unless indicated otherwise in a credit line to the material. If material is not included in the article's Creative Commons licence and your intended use is not permitted by statutory regulation or exceeds the permitted use, you will need to obtain permission directly from the copyright holder. To view a copy of this licence, visit http://creativecommons.org/licenses/by/4.0/.

\section{References}

1. Gribble FM, Reimann F (2016) Enteroendocrine cells: chemosensors in the intestinal epithelium. Annu Rev Physiol 78: 277-299. https://doi.org/10.1146/annurev-physiol-021115-105439

2. Müller TD, Finan B, Bloom SR et al (2019) Glucagon-like peptide 1 (GLP-1). Mol Metab 30:72-130. https://doi.org/10.1016/j. molmet.2019.09.010

3. Grosse J, Heffron H, Burling K et al (2014) Insulin-like peptide 5 is an orexigenic gastrointestinal hormone. Proc Natl Acad Sci U S A 111(30):11133-11138. https://doi.org/10.1073/pnas.1411413111

4. Billing LJ, Smith CA, Larraufie P et al (2018) Co-storage and release of insulin-like peptide-5, glucagon-like peptide-1 and peptideYY from murine and human colonic enteroendocrine cells. Mol Metab 16:65-75. https://doi.org/10.1016/j.molmet.2018.07. 011

5. Holst JJ (2007) The physiology of glucagon-like peptide 1. Physiol Rev 87(4):1409-1439. https://doi.org/10.1152/physrev.00034. 2006

6. Reimann F, Habib AM, Tolhurst G, Parker HE, Rogers GJ, Gribble FM (2008) Glucose sensing in L cells: a primary cell study. Cell Metab 8(6):532-539. https://doi.org/10.1016/j.cmet.2008.11.002

7. Parker HE, Adriaenssens A, Rogers G et al (2012) Predominant role of active versus facilitative glucose transport for glucagonlike peptide-1 secretion. Diabetologia 55(9):2445-2455. https:// doi.org/10.1007/s00125-012-2585-2
8. Gorboulev V, Schürmann A, Vallon Vet al (2012) Na(+)-D-glucose cotransporter SGLT1 is pivotal for intestinal glucose absorption and glucose-dependent incretin secretion. Diabetes 61(1):187-196. https://doi.org/10.2337/db11-1029

9. Kuhre RE, Christiansen CB, Saltiel MY, Wewer Albrechtsen NJ, Holst JJ (2017) On the relationship between glucose absorption and glucose-stimulated secretion of GLP-1, neurotensin, and PYY from different intestinal segments in the rat. Physiol Rep 5(23). https:// doi.org/10.14814/phy2.13507

10. Tolhurst G, Heffron H, Lam YS et al (2012) Short-chain fatty acids stimulate glucagon-like peptide-1 secretion via the G-proteincoupled receptor FFAR2. Diabetes 61(2):364-371. https://doi.org/ $10.2337 / \mathrm{db} 11-1019$

11. Christiansen CB, Trammell SAJ, Wewer Albrechtsen NJ et al (2019) Bile acids drive colonic secretion of glucagon-like-peptide 1 and peptide-YY in rodents. Am J Physiol Gastrointest Liver Physiol 316(5):G574-G584. https://doi.org/10.1152/ajpgi.00010. 2019

12. Christiansen CB, Gabe MBN, Svendsen B, Dragsted LO, Rosenkilde MM, Holst JJ (2018) The impact of short-chain fatty acids on GLP-1 and PYY secretion from the isolated perfused rat colon. Am J Physiol Gastrointest Liver Physiol 315(1):G53-G65. https://doi.org/10.1152/ajpgi.00346.2017

13. Pais R, Rievaj J, Larraufie P, Gribble F, Reimann F (2016) Angiotensin II type 1 receptor-dependent GLP-1 and PYY secretion in mice and humans. Endocrinology 157(10):3821-3831. https://doi.org/10.1210/en.2016-1384

14. Pais R, Rievaj J, Meek C et al (2016) Role of enteroendocrine Lcells in arginine vasopressin-mediated inhibition of colonic anion secretion. J Physiol 594(17):4865-4878. https://doi.org/10.1113/ JP272053

15. Chambers AP, Sorrell JE, Haller A et al (2017) The role of pancreatic preproglucagon in glucose homeostasis in mice. Cell Metab 25(4):927-934.e923. https://doi.org/10.1016/j.cmet.2017.02.008

16. Kim KS, Hutch CR, Wood L, Magrisso IJ, Seeley RJ, Sandoval DA (2019) Glycemic effect of pancreatic preproglucagon in mouse sleeve gastrectomy. JCI Insight 4(20). https://doi.org/10.1172/jci. insight. 129452

17. Song Y, Koehler JA, Baggio LL, Powers AC, Sandoval DA, Drucker DJ (2019) Gut-proglucagon-derived peptides are essential for regulating glucose homeostasis in mice. Cell Metab 30(5):976986.e973. https://doi.org/10.1016/j.cmet.2019.08.009

18. Biggs EK, Liang L, Naylor J et al (2018) Development and characterisation of a novel glucagon like peptide-1 receptor antibody. Diabetologia 61(3):711-721. https://doi.org/10.1007/s00125-0174491-0

19. Larraufie P, Roberts GP, McGavigan AK et al (2019) Important role of the GLP-1 Axis for glucose homeostasis after bariatric surgery. Cell Rep 26(6):1399-1408.e1396. https://doi.org/10.1016/j.celrep. 2019.01.047

20. Frayn KN (1983) Calculation of substrate oxidation rates in vivo from gaseous exchange. J Appl Physiol Respir Environ Exerc Physiol 55(2):628-634. https://doi.org/10.1152/jappl.1983.55.2. 628

21. Adriaenssens AE, Biggs EK, Darwish T et al (2019) Glucosedependent insulinotropic polypeptide receptor-expressing cells in the hypothalamus regulate food intake. Cell Metab 30(5):987996.e986. https://doi.org/10.1016/j.cmet.2019.07.013

22. Billing LJ, Larraufie P, Lewis J et al (2019) Single cell transcriptomic profiling of large intestinal enteroendocrine cells in mice - identification of selective stimuli for insulin-like peptide-5 and glucagon-like peptide-1 co-expressing cells. Mol Metab 29: 158-169. https://doi.org/10.1016/j.molmet.2019.09.001

23. Dun SL, Brailoiu E, Wang Y et al (2006) Insulin-like peptide 5: expression in the mouse brain and mobilization of calcium. 
Endocrinology 147(7):3243-3248. https://doi.org/10.1210/en. 2006-0237

24. Roth BL (2016) DREADDs for neuroscientists. Neuron 89(4):683694. https://doi.org/10.1016/j.neuron.2016.01.040

25. Sheng K, Zhang H, Yue J, Gu W, Gu C, Wu W (2018) Anorectic response to the trichothecene T-2 toxin correspond to plasma elevations of the satiety hormone glucose-dependent insulinotropic polypeptide and peptide YY. Toxicology 402-403:28-36. https://oi. org/10.1016/j.tox.2018.04.007

26. Shoblock JR, Welty N, Nepomuceno D et al (2010) In vitro and in vivo characterization of JNJ-31020028 (N-(4-\{4-[2(diethylamino)-2-oxo-1-phenylethyl]piperazin-1-yl\}-3fluorophenyl)-2-pyridin-3-ylbenzamide), a selective brain penetrant small molecule antagonist of the neuropeptide Y Y(2) receptor. Psychopharmacology 208(2):265-277. https://doi.org/10.1007/ s00213-009-1726-x

27. Tough IR, Forbes S, Tolhurst R et al (2011) Endogenous peptide YY and neuropeptide $\mathrm{Y}$ inhibit colonic ion transport, contractility and transit differentially via $\mathrm{Y}_{1}$ and $\mathrm{Y}_{2}$ receptors. Br J Pharmacol 164(2b):471-484. https://doi.org/10.1111/j.1476-5381.2011. 01401.x

28. Hutch CR, Roelofs K, Haller A et al (2019) The role of GIP and pancreatic GLP-1 in the glucoregulatory effect of DPP-4 inhibition in mice. Diabetologia 62(10):1928-1937. https://doi.org/10.1007/ s00125-019-4963-5

29. Orskov C, Holst JJ, Poulsen SS, Kirkegaard P (1987) Pancreatic and intestinal processing of proglucagon in man. Diabetologia 30(11):874-881. https://doi.org/10.1007/bf00274797

30. Svendsen B, Larsen O, Gabe MBN et al (2018) Insulin secretion depends on intra-islet glucagon signaling. Cell Rep 25(5):11271134.e1122. https://doi.org/10.1016/j.celrep.2018.10.018

31. Rouillé Y, Westermark G, Martin SK, Steiner DF (1994) Proglucagon is processed to glucagon by prohormone convertase PC2 in alpha TC1-6 cells. Proc Natl Acad Sci U S A 91(8):3242 3246. https://doi.org/10.1073/pnas.91.8.3242

32. Nauck MA, El-Ouaghlidi A, Gabrys B et al (2004) Secretion of incretin hormones (GIP and GLP-1) and incretin effect after oral glucose in first-degree relatives of patients with type 2 diabetes. Regul Pept 122(3):209-217. https://doi.org/10.1016/j.regpep. 2004.06.020

33. Ellingsgaard H, Hauselmann I, Schuler B et al (2011) Interleukin-6 enhances insulin secretion by increasing glucagon-like peptide-1 secretion from L cells and alpha cells. Nat Med 17(11):14811489. https://doi.org/10.1038/nm.2513

34. Capozzi ME, Wait JB, Koech J, et al. (2019) Glucagon lowers glycemia when $\beta$-cells are active. JCI Insight 5. https://doi.org/10. 1172/jci.insight. 129954

35. Capozzi ME, Svendsen B, Encisco SE, et al. (2019) $\beta$ Cell tone is defined by proglucagon peptides through cAMP signaling. JCI Insight 4(5). https://doi.org/10.1172/jci.insight. 126742

36. Zhu L, Dattaroy D, Pham J, et al. (2019) Intra-islet glucagon signaling is critical for maintaining glucose homeostasis. JCI Insight 5. https://doi.org/10.1172/jci.insight.127994

37. Andersson H, Alestig K (1976) The penetration of doxycycline into CSF. Scand J Infect Dis Suppl(9): 17-19

38. Lee YS, De Vadder F, Tremaroli V et al (2016) Insulin-like peptide 5 is a microbially regulated peptide that promotes hepatic glucose production. Mol Metab 5(4):263-270. https://doi.org/10.1016/j. molmet.2016.01.007

39. Luo X, Li T, Zhu Y et al (2015) The insulinotrophic effect of insulin-like peptide 5 in vitro and in vivo. Biochem J 466(3):467473. https://doi.org/10.1042/BJ20141113
40. Zaykov AN, Gelfanov VM, Perez-Tilve D, Finan B, DiMarchi RD (2019) Insulin-like peptide 5 fails to improve metabolism or body weight in obese mice. Peptides 120:170116. https://doi.org/10. 1016/j.peptides.2019.170116

41. Pocai A (2014) Action and therapeutic potential of oxyntomodulin. Mol Metab 3(3):241-251. https://doi.org/10.1016/j.molmet.2013. 12.001

42. Liu YL, Ford HE, Druce MR et al (2010) Subcutaneous oxyntomodulin analogue administration reduces body weight in lean and obese rodents. Int J Obes 34(12):1715-1725. https://doi. org/10.1038/ijo.2010.110

43. Pascual D, Alsasua A, Goicoechea C, Martín MI (2002) The involvement of 5-HT3 and 5-HT4 receptors in two models of gastrointestinal transit in mice. Neurosci Lett 326(3):163-166. https://doi.org/10.1016/s0304-3940(02)00251-3

44. Wang L, Martínez V, Kimura H, Taché Y (2007) 5 Hydroxytryptophan activates colonic myenteric neurons and propulsive motor function through 5-HT4 receptors in conscious mice. Am J Physiol Gastrointest Liver Physiol 292(1):G419G428. https://doi.org/10.1152/ajpgi.00289.2006

45. Heredia DJ, Gershon MD, Koh SD, Corrigan RD, Okamoto T, Smith TK (2013) Important role of mucosal serotonin in colonic propulsion and peristaltic reflexes: in vitro analyses in mice lacking tryptophan hydroxylase 1. J Physiol 591(23):5939-5957. https:// doi.org/10.1113/jphysiol.2013.256230

46. Glass LL, Calero-Nieto FJ, Jawaid W et al (2017) Single-cell RNAsequencing reveals a distinct population of proglucagon-expressing cells specific to the mouse upper small intestine. Mol Metab 6(10): 1296-1303. https://doi.org/10.1016/j.molmet.2017.07.014

47. Lund ML, Egerod KL, Engelstoft MS et al (2018) Enterochromaffin 5-HT cells - a major target for GLP-1 and gut microbial metabolites. Mol Metab 11:70-83. https://doi.org/10. 1016/j.molmet.2018.03.004

48. Bellono NW, Bayrer JR, Leitch DB et al (2017) Enterochromaffin cells are gut chemosensors that couple to sensory neural pathways. Cell 170(1):185-198.e116. https://doi.org/10.1016/j.cell.2017.05. 034

49. Forbes SC, Cox HM (2014) Peptide YY, neuropeptide Y and corticotrophin-releasing factor modulate gastrointestinal motility and food intake during acute stress. Neurogastroenterol Motil 26(11):1605-1614. https://doi.org/10.1111/nmo.12428

50. Chambers ES, Viardot A, Psichas A et al (2015) Effects of targeted delivery of propionate to the human colon on appetite regulation, body weight maintenance and adiposity in overweight adults. Gut 64(11):1744-1754. https://doi.org/10.1136/gutjnl-2014-307913

51. Adrian TE, Gariballa S, Parekh KA et al (2012) Rectal taurocholate increases $\mathrm{L}$ cell and insulin secretion, and decreases blood glucose and food intake in obese type 2 diabetic volunteers. Diabetologia 55(9):2343-2347. https://doi.org/10.1007/s00125-012-2593-2

52. Brighton CA, Rievaj J, Kuhre RE et al (2015) Bile acids trigger GLP-1 release predominantly by accessing basolaterally located G protein-coupled bile acid receptors. Endocrinology 156(11):39613970. https://doi.org/10.1210/en.2015-1321

53. Christensen LW, Kuhre RE, Janus C, Svendsen B, Holst JJ (2015) Vascular, but not luminal, activation of FFAR1 (GPR40) stimulates GLP-1 secretion from isolated perfused rat small intestine. Physiol Rep 3(9). https://doi.org/10.14814/phy2.12551

Publisher's note Springer Nature remains neutral with regard to jurisdictional claims in published maps and institutional affiliations. 